\title{
Cognitive Archetypes, Acculturation and Social Coping Trends among Small Scale Muslim Merchants in A Public Market in the Philippines
}

Sherill S. Villaluz

To Link this Article: http://dx.doi.org/10.6007/IJARBSS/v11-i5/10013

DOI:10.6007/IJARBSS/v11-i5/10013

Received: 15 March 2021, Revised: 17 April 2021, Accepted: 13 May 2021

Published Online: 25 May 2021

In-Text Citation: (Villaluz, 2021)

To Cite this Article: Villaluz, S. S. (2021). Cognitive Archetypes, Acculturation and Social Coping Trends among Small Scale Muslim Merchants in A Public Market in the Philippines. International Journal of Academic Research in Business and Social Sciences, 11(5), 639-654.

Copyright: (c) 2021 The Author(s)

Published by Human Resource Management Academic Research Society (www.hrmars.com) This article is published under the Creative Commons Attribution (CC BY 4.0) license. Anyone may reproduce, distribute, translate and create derivative works of this article (for both commercial and non-commercial purposes), subject to full attribution to the original publication and authors. The full terms of this license may be seen at: http://creativecommons.org/licences/by/4.0/legalcode

Vol. 11, No. 5, 2021, Pg. 639 - 654

Full Terms \& Conditions of access and use can be found at http://hrmars.com/index.php/pages/detail/publication-ethics 


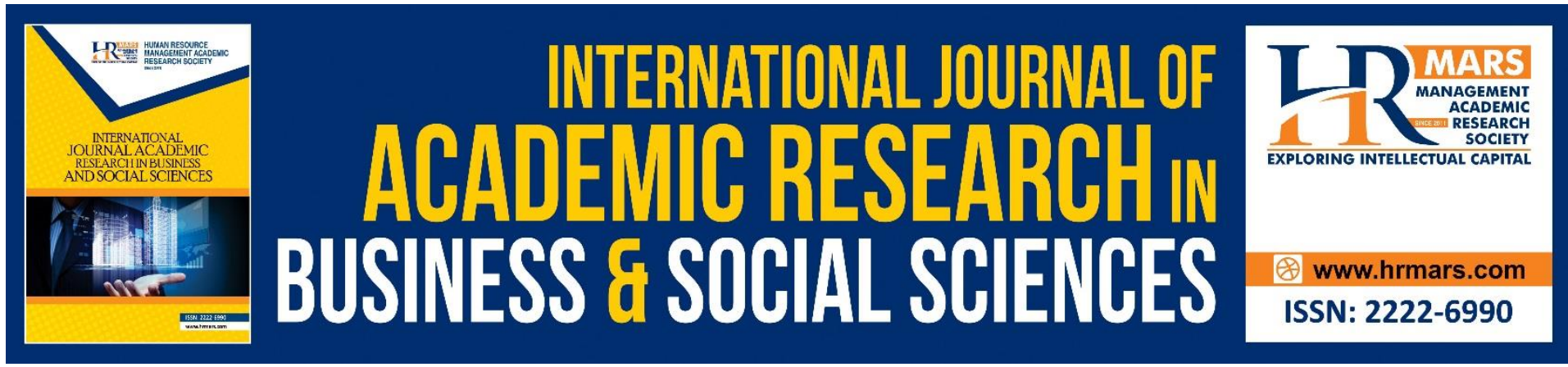

\title{
Cognitive Archetypes, Acculturation and Social Coping Trends among Small Scale Muslim Merchants in A Public Market in the Philippines
}

\author{
Sherill S. Villaluz \\ Faculty, College of Arts and Sciences University of Perpetual Help System Laguna \\ Laguna, Philippines \\ Email: villaluz.sherill@uphsl.edu.ph
}

\begin{abstract}
Muslim settlers in Laguna, Philippines has increased over the years, thus it is important to understand their dominant cognitive archetypes that may be credited for their vulnerability to acquire behavior from their new environment. This could enable them to utilize the best coping strategy. Although a considerable review of literature and studies exist about archetypes, acculturation and social coping trends of individuals, scant attention has been given to Muslim migrants especially in the context of trade and business in local public market. This descriptive-correlational study determined how the cognitive archetypes of 110 randomly selected Muslim merchants are related to their level of acculturation and to their central social coping trend, and how their level of acculturation is related to their central social coping trend. Findings revealed that the respondents manifested the Great Mother archetype, have low level of acculturation and utilized the moving-away-from-people social coping trend. Moreover, rest of relationship revealed that the lower the respondents' level of acculturation, the more they tend to move away from people displaying the detached type of personality.
\end{abstract}

Keywords: Descriptive Correlational Study, Southeast Asia, Quantitative Research, Psychology.

\section{Introduction}

Due to the modern era of globalization as well as inter-racial and religious conflicts, Muslim migrants are now seen settling in different areas all over the world (Inglehart \& Norris, 2009 . The presence of Muslims migrants had sparked debate, controversy, fear and even hatred (Khader, 2016). Even before the arrival of Spanish colonizers and Roman Catholicism in the Philippines, Islam was already present in the country. Introduced by Muslim traders in southern Philippines in the 14th century, Islam's influence had once spread north to Manila. Many centuries later, Islam continues to be an integral part of Philippine history and culture (Bueza, 2015). In some countries, concerns about Islam immigrants were being raised. In fact, integration of Muslim immigrants has become an increasingly important policy issue in Europe and North America over the last twenty years due to marked growth in the number of Muslim immigrants, the refugee crisis, and the current geopolitical turbulence between 
Western nations and political Islamist groups (Liebert et. al., 2020). In a study by Salma and Salami (2020), not all Muslim immigrants who participated in the study reported feelings of isolation and loneliness in their host country because many of them are able to adopt proactive counter measures. Understanding how people behave in certain way has always been of great interest among researchers.

Numerous researches have revealed that an individual's personality does not only concentrate on personal identity alone. Although it is true that we have our own view of our self, there is also the social identity which encompass the social component of who we are. This might include the social roles that we play, the influences from the people around us, and our cultural values which in one way or another contribute to our sense of self (Swann \& Bosson, 2008; Bodycott, 2015). Another leading school of thought in understanding one's personality is the existence of one's collective unconscious that house primordial images such as the archetypes (Burger, 2012). Cognitive archetype is sophisticated framework that typifies human behavior that makes them unique in their own way (Narang, et.al., 2019).

The term "archetype" has its origins in ancient Greek. The root words are archein, which means "original or old"; and typos, which means "pattern, model or type". Carl Gustav Jung, a known psychodynamic theorist popularized the use of archetype in understanding human psyche. He believed that universal, mythic character-archetypes reside within the collective unconscious of people all over the world. These archetypes are considered as the themes of our experience and that they evoke deep emotions. Each type has its own set of values, meanings and personality traits and that one or combination of it, tends to dominate one's personality in general (Golden, 2013). Archetypes guide people's every action and decision by embodying characteristic motives and qualities associated to it (Munteanua, Costeaa, Palosa, \& Jinaru, 2010). Additionally, archetypes are the means of action and may take the form of images, dreams, or they are a stimulus to a specific action. Jung says that dreams are archetypal guidance and are the wisdom of past generations (Adamski, 2011). This study focused on the five cognitive archetypes that might apply to the dominant personality traits of the respondents. These are the (1) Wise old man archetype which is stoic and contemplative, wise but in no hurry; the (2) Hero who are typically strong and perseverant, with boundless ambition; the (3) Caregiver who are typically compassionate and caring, always putting the needs of others before themselves; the (4) Great Father who are typically a keeper of order and sanity; and the (5) Great Mother who typifies those who are intuitive, empathic and always ready to listen (Golden, 2013).

For researchers in the field of personality psychology, it is interesting to know if it is possible that people's dominant cognitive archetype could be directly linked to some other traits and tendencies they manifest. The study of Munteanu et al., (2010), proves this by concluding that dominant archetype is linked with several personality types. Another on how the cognitive archetypes could be driving force to direct one's individuality was the one conducted by Jamalinesari \& Feilinez (2015) had who concluded that men's archetype drives them to continuously search for meaning and sense of self. Will this be the case for the Muslim migrants in the municipality of Binan?

It is quite ordinary to see people opt to settle in places away from their native land, and respondents of this study are perfect example. As expected, they are exposed to 
traditions, cultures and beliefs which may be quite different from what they are accustomed to. This is where the acculturation comes in. Acculturation in a concept introduced by Schumann (1986) as cited in Zaker (2016) which involves the process of social, psychological, and cultural change that stems from the balancing of two cultures while adapting to the prevailing culture of the society. True enough, when one decided to transfer his residence, a sort of acculturation could possibly change place changing some of his lifestyle, his language, and even his beliefs. In a clear sense of it, the word 'acculturation' is the act of that transition (McCallister, 2018). At some point, a certain degree of transition in one's lifestyle may result to acculturative stress, which could be overcome based on one's orientation and social support. In a study conducted by Sullivan and Kashubeck-West (2015), they found out that international students with broad-based social support and an integration approach to acculturation experienced lower levels of acculturative stress. Another factor that may be related to immigrants' level of acculturation would be their cultural rootedness. The study of Lee and Negrelli (2018) stressed that cultural identification that is rooted in one's cognition, emotion and behavior are significant factors that might affect one's degree of acculturation.

As to be expected, migrants are faced with a lot of challenges and difficulties which could possibly lead to anxiety and conflicts (Bazezew \& Neka, 2017). In some cases, racial isolation as experienced by some migrants might also result to poor performance (Sharma, et.al., 2014). This is where social coping trends would come to play (Harlow, 2016). There are those who move toward other people and capitalize on dependence. They seek affection and approval from others and avoids aggression, thus manifests compliant personality. Yet another coping trend is moving away from others and removes themselves from the source of anxiety. This detachment rooted from their belief that the world will disappoint them so they withdraw from it. Lastly, there are those individuals who move against others as a form of solutions to their problems and that power, prestige and admiration is important to them (Harris, 2016). One's social coping trend might affect one's tendency to cope with conflict and even depression as concluded by Eberhart and Hammen (2010). On such premise, it is important to improve coping trends to improve one's behavior (Tessier, Sarrazin \& Sarrazin, 2010).

This study was anchored on the Evolutionary Theory of Personality proposed by David Buss (Buss, 2009). Buss's definition of personality was derived from the evolutionary perspective of psychological thought and behavior. He defines personality as an adaptive process which is an evolved strategy that solve important survival and/or reproductive problems (Masanda, 2018). With the predominant personality traits and tendencies rooted in people's cognitive archetypes, people manifest individual differences that could be credited for people's vulnerability to acquire new culture from their new environment (Buss \& Hawley, 2011). This in turn will enable them to utilize what they believe is the best coping strategy to be used.

Due to globalization and migration processes, there is a need to assess migrants' personality functioning so they be better live in their new environments (Ziegenbein et al., 2008). There are a number of reasons why some Muslims from Mindanao opted to settle in Laguna, top of which are political and social developments (Fassaert et al., 2011). This is true to the case of the Muslim merchants who resettle in Binan, along with the belief that better economic opportunities are in such province. Although numerous studies on acculturation 
and coping trends are available, there is none that concentrates on the cognitive archetypes and how it could be related to the tendency of migrants to acquire new culture in turn, would enable them to cope with their new environment.

The goal of this research is to shed light on the following concerns:

- Identify the respondents' cognitive archetype in terms of (1) Wise old manStoic; (2) Hero; (3) Caregiver; (4) Great father: and (5) Great mother.

- Identify the respondents' level of acculturation,;

- Determine their central social coping trend along (1) Moving towards people (compliant personality); (2) Moving against people (aggressive personality), and (3) Moving away from people (detached personality.

- Identify how the respondents' cognitive archetypes significantly relate to their level of acculturation and to their central social coping trend; and

- Find out how the respondents' level of acculturation significantly relates to their central social coping trend.

\section{Materials and Methods}

The respondents of this descriptive-correlational study were 110 out of 330 Muslims who were purposively chosen since they fit the criteria of being residents of Binan, Laguna, have small scale business based in Binan Public Market and had been operating their business for about 5 to 10 years. Vendors were classified according to the type of products they sell. Random selection was employed for the respondents who were grouped as to garments, footwear and mobile gadgets. Proportional sampling was utilized for distributing research instruments to 110 respondents, with 37 each for the first two groups and 36 for the last. Simple lottery method was used to select the actual respondents. The researcher used a questionnaire for the purpose of collecting the needed data. It was divided into two (3) parts: part 1 identified the respondents' cognitive archetype as to wise old man, hero, caregiver, great father, and great mother with 5 indicators for each archetype; part 2 measured the respondents' level of acculturation with 15 indicators and part 3 focused on the respondents' central social coping trends in terms of moving towards people (compliant personality), against people (aggressive personality), and away from people (detached personality). To ensure validity, the instrument was validated by experts in psychology, research and statistics and yielded a reliability Cronbach's Alpha result of 0.713 .

The questionnaire was considered as the most appropriate data-gathering instrument for this descriptive research study. Respondents were being oriented on the nature and depth of the study. After they expressed their consent to participate of the study they were given direction on how to respond to the instrument and they were assured of the confidentiality of their responses. After the respondents accomplished the questionnaire, the researcher retrieved them. Data were then tallied, statistically treated, analyzed and interpreted.

Weighted mean was used to describe the respondents' cognitive archetypes, their level of acculturation, and their central social coping trend. The following measures were used for the respondents' cognitive archetypes and their central social coping trends: (4) 3.51-4.00 for very true of me, (3) 2.51-3.50 for true of me, (2) 1.51-2.50 for untrue of me and (1) 1.001.50 for very untrue of me. For the respondents' level of acculturation, the following 
measures and interpretations were used: (4) 3.51-4.00 for very true of me/Very High Level, (3) 2.51-3.50 for true of me/High Level, (2) 1.51-2.50 for untrue of me/ Low Level and (1) 1.001.50 for very untrue of me/Very Low Level. Pearson $r$ was used to determine the relationship between their cognitive archetype and their level of acculturation, their cognitive archetypes and their central social coping trend, and their level of acculturation and their central social coping trend.

\section{Results and Discussions}

Discussion of the respondents' cognitive archetypes, their level of acculturation, their central social coping trends and the relationship among them are presented in the succeeding paragraphs.

Table 1

The Respondents' Cognitive Archetype

\begin{tabular}{|c|c|c|c|}
\hline Indicators & $\begin{array}{l}\text { Weighte } \\
\text { d Mean }\end{array}$ & $\begin{array}{l}\text { Verbal } \\
\text { Interpretatio } \\
\mathbf{n} \\
\end{array}$ & Rank \\
\hline \multicolumn{4}{|l|}{ Wise old man } \\
\hline 1. I consider myself as an enduring person. & 3.22 & True of me & \\
\hline 2. I like to be alone to reflect on my thoughts. & 3.24 & True of me & \\
\hline 3. I like to take things one step at a time. & 3.12 & True of me & \\
\hline $\begin{array}{l}\text { 4. I believe it is important to be optimistic in facing life's } \\
\text { challenges. }\end{array}$ & 3.22 & True of me & \\
\hline $\begin{array}{l}\text { 5. I show encourage people to be hopeful despite having } \\
\text { problems. }\end{array}$ & 3.08 & True of me & \\
\hline Average & 3.17 & True of me & 2.5 \\
\hline Hero & & True of me & \\
\hline 1. I do my best to win in competitions that I join in. & 3.26 & True of me & \\
\hline 2. I do my best to make sure that I will achieve my life's goals. & 3.22 & True of me & \\
\hline 3. I consider myself as a hardworking person. & 3.11 & True of me & \\
\hline 4. I see myself as tolerant and persevering individual. & 3.12 & True of me & \\
\hline $\begin{array}{l}\text { 5. I like to challenge myself to surpass my personal } \\
\text { achievements. }\end{array}$ & 3.15 & True of me & \\
\hline Average & 3.17 & True of me & 2.5 \\
\hline Great mother & & True of me & \\
\hline 1. I make myself available to listen to other people's problems. & 3.12 & True of me & \\
\hline 2. I often worry for the sake of others. & 3.23 & True of me & \\
\hline 3. I'm a person who easily feels what other people are feeling. & 3.21 & True of me & \\
\hline $\begin{array}{l}\text { 4. I am good at sensing when people are going through } \\
\text { difficult times. }\end{array}$ & 3.21 & True of me & \\
\hline $\begin{array}{l}\text { 5. I make sure to spend quality time with my friends and } \\
\text { family. }\end{array}$ & 3.17 & True of me & \\
\hline Average & 3.19 & True of me & 1 \\
\hline Great father & & True of me & \\
\hline $\begin{array}{l}\text { 1. I make sure to help people solve their interpersonal } \\
\text { conflicts. }\end{array}$ & 3.11 & True of me & \\
\hline
\end{tabular}




\begin{tabular}{|l|l|l|l|}
\hline 2. I make sure to maintain peace and order in the community. & 3.18 & True of me & \\
\hline $\begin{array}{l}\text { 3. I believe there all misunderstanding could be settled } \\
\text { through good communication. }\end{array}$ & 3.14 & True of me & \\
\hline 4. I believe that honesty is the best policy. & 3.17 & True of me & \\
\hline 5. I believe in life, it is important to follow rules. & 3.12 & True of me & \\
\hline Average & 3.14 & True of me & $\mathbf{4}$ \\
\hline Caregiver & & True of me & \\
\hline $\begin{array}{l}\text { 1. I try to empathize with other people } \\
\text { 2. I care for people whatever their race or background }\end{array}$ & 3.14 & True of me & \\
\hline $\begin{array}{l}\text { 3. I like giving advice to friends who often experience troubles } \\
\text { in life }\end{array}$ & 3.05 & True of me & True of me \\
\hline $\begin{array}{l}\text { 4. I am willing to put off my personal interest to give way to } \\
\text { people in need }\end{array}$ & 2.97 & True of me & \\
\hline 5. I like donating to charities. & $\mathbf{2 . 9 9}$ & True of $\mathbf{m e}$ & $\mathbf{5}$ \\
\hline Average & $\mathbf{3 . 0 6}$ & True of me & $\mathbf{5}$ \\
\hline Overall Average & $\mathbf{3 . 1 5}$ & True of me & \\
\hline
\end{tabular}

Table 1 shows the respondents' cognitive archetypes. It showed that the respondents claimed that they primarily possess the cognitive archetype of being Great Mother, having obtained the highest average weighted mean of 3.19 interpreted as true of me. Highest among the indicators were the items "I'm a person who easily feels what other people are feeling: and "I am good at sensing when people are going through difficult times" ( $\chi 3.21)$ interpreted as true of me. Second highest cognitive archetype shown by the respondents were the Wise Old Man and Hero with an average weighted mean of 3.17 respectively, both interpreted as true of me while last in rank is Caregiver with an average of 3.06 interpreted as true of me

With the Great Mother as the dominant cognitive archetype displayed by the respondents, they have the tendency to manifest essential traits of mothers such as their cherishing and nourishing goodness who shows genuine empathy (Purrington, 2019). It was mentioned in the study of Villate (2012) that each archetype has an associated task which serve specific purpose for the individual, like the Great Mother archetype whose accompanied by the gift of compassion and altruism. In the case of migrants, it is important to support each other highlighting important values such as empathy, respect, acceptance and appreciation (Juaseekoon, et.al.,2017). 
Table 2

The Respondents' Level of Acculturation

\begin{tabular}{|c|c|c|c|}
\hline Indicators & $\begin{array}{l}\text { Weighted } \\
\text { Mean }\end{array}$ & $\begin{array}{c}\text { Verbal } \\
\text { Interpretation }\end{array}$ & Rank \\
\hline $\begin{array}{l}\text { 1. I feel that both Muslims and Non-Muslims value me } \\
\text { as a person. }\end{array}$ & 2.49 & $\begin{array}{l}\text { (Untrue of me) } \\
\text { Low }\end{array}$ & 9 \\
\hline $\begin{array}{l}\text { 2. I feel comfortable around both Muslims and Non- } \\
\text { Muslims in Binan. }\end{array}$ & 2.46 & $\begin{array}{l}\text { (Untrue of me) } \\
\text { Low }\end{array}$ & 10 \\
\hline $\begin{array}{l}\text { 3. I also use Tagalog in communicating with others } \\
\text { aside from my native dialect. }\end{array}$ & 2.35 & $\begin{array}{l}\text { (Untrue of me) } \\
\text { Low }\end{array}$ & 11 \\
\hline $\begin{array}{l}\text { 4. I am willing to go to social gatherings where there are } \\
\text { both Muslims and Non-Muslims. }\end{array}$ & 1.59 & $\begin{array}{l}\text { (Untrue of me) } \\
\text { Low }\end{array}$ & 12 \\
\hline $\begin{array}{l}5 . \text { I can write both in my native language and in } \\
\text { Tagalog. }\end{array}$ & 1.38 & $\begin{array}{l}\text { (Untrue of me) } \\
\text { Low }\end{array}$ & 13 \\
\hline $\begin{array}{l}\text { 6. I can trust the people in Binan just how I can trust my } \\
\text { fellow-Muslim. }\end{array}$ & 2.58 & $\begin{array}{l}\text { (True of me) } \\
\text { High }\end{array}$ & 7 \\
\hline 7. I find the people in Binan easy to understand me. & 2.54 & $\begin{array}{l}\text { (True of me) } \\
\text { High }\end{array}$ & 8 \\
\hline $\begin{array}{l}\text { 8. It is easy for me to make friends with the people in } \\
\text { Binan. }\end{array}$ & 2.71 & $\begin{array}{l}\text { (True of me) } \\
\text { High }\end{array}$ & 6 \\
\hline 9. I feel accepted by the people in Binan. & 2.96 & $\begin{array}{l}\text { (True of me) } \\
\text { High }\end{array}$ & 3 \\
\hline $\begin{array}{l}\text { 10. I feel that the people in Binan respect my beliefs } \\
\text { and principles. }\end{array}$ & 2.84 & $\begin{array}{l}\text { (True of me) } \\
\text { High }\end{array}$ & 5 \\
\hline $\begin{array}{l}11 . \text { I see myself comfortably living in Binan for the next } \\
10 \text { years. }\end{array}$ & 2.99 & $\begin{array}{l}\text { (True of me) } \\
\text { High }\end{array}$ & 1.5 \\
\hline $\begin{array}{l}\text { 12. I do appreciate how the residents of Binan manage } \\
\text { to live their lives. }\end{array}$ & 2.93 & $\begin{array}{l}\text { (True of me) } \\
\text { High }\end{array}$ & 4 \\
\hline $\begin{array}{l}\text { 13. I learn to adapt to the values and principles of the } \\
\text { residents in Binan. }\end{array}$ & 1.29 & $\begin{array}{c}\text { (Very untrue } \\
\text { of me) } \\
\text { Very Low }\end{array}$ & 14 \\
\hline $\begin{array}{l}\text { 14. I can comfortably crack jokes with the residents of } \\
\text { Binan. }\end{array}$ & 2.99 & $\begin{array}{l}\text { (True of me) } \\
\text { High }\end{array}$ & 1.5 \\
\hline $\begin{array}{l}\text { 15. I can discuss some of my personal concerns with my } \\
\text { friends in Binan. }\end{array}$ & 1.18 & $\begin{array}{c}\text { (Very untrue } \\
\text { of me) } \\
\text { Very Low }\end{array}$ & 15 \\
\hline Average & 2.35 & $\begin{array}{l}\text { Untrue of me } \\
\quad \text { (Low) }\end{array}$ & \\
\hline
\end{tabular}

On the respondents' level of acculturation, the table shows that 8 among the 15indicators were true (high level of acculturation) to the respondents while the remaining indicators were either untrue or very untrue (low or very low level of acculturation) to the respondents. True to the respondents were the indicators "I see myself comfortably living in Binan for the next 10 years" and "I can comfortably crack jokes with the residents of Binan" being both on top rank with an average weighted mean of 2.99 verbally interpreted as high level of acculturation. Very untrue to the respondents were the indicators "I learn to adapt to the values and principles of the residents in Binan" and "I can discuss some of my personal 
concerns with my friends in Binan" having obtained the weighted mean of 1.29 and 1.18 respectively verbally interpreted as very low. The average weighted mean of 2.35 (untrue of me) implied that the respondents had low level of acculturation. This means that the respondents did not necessarily embrace the changes even they are in contact with culturally different people of social influences (Schwartz, et.al., 2010).

Frazer et.al. (2017) mentioned in their study the concept of acculturation dissonance or discrepant family cultural orientations. It was further argued that it could be difficult and challenging for immigrants to retain their native cultural values while attaining cultural compatibility to their host culture (Telzer, 2011).

Table 3

The Respondents' Social Coping Trend

\begin{tabular}{|c|c|c|c|}
\hline Indicators & $\begin{array}{l}\text { Weighted } \\
\text { Mean }\end{array}$ & $\begin{array}{c}\text { Verbal } \\
\text { Interpretation }\end{array}$ & Rank \\
\hline \multicolumn{4}{|l|}{ Moving towards people (compliant personality) } \\
\hline $\begin{array}{l}\text { 1. I am willing to compromise what I believe in in } \\
\text { exchange of people's approval. }\end{array}$ & 2.65 & True of me & \\
\hline $\begin{array}{l}\text { 2. I am submissive to people who are in control of the } \\
\text { situations. }\end{array}$ & 2.88 & True of me & \\
\hline $\begin{array}{l}\text { 3. I am attracted to people who have dominant } \\
\text { personality. }\end{array}$ & 2.65 & True of me & \\
\hline $\begin{array}{l}\text { 4. I would do anything to be accepted in the society } \\
\text { that I live in. }\end{array}$ & 2.71 & True of me & \\
\hline $\begin{array}{l}\text { 5. I know it gives me a sense of pride knowing that } \\
\text { people like me. }\end{array}$ & 2.72 & True of me & \\
\hline Average & 2.72 & True of me & 2 \\
\hline \multicolumn{4}{|l|}{ Moving against people (aggressive personality) } \\
\hline 1. I make sure that I influence people with my ideas. & 2.33 & Untrue of me & \\
\hline $\begin{array}{l}\text { 2. I believe it is important to show people that you are } \\
\text { powerful and influential. }\end{array}$ & 2.35 & Untrue of me & \\
\hline $\begin{array}{l}\text { 3. I make sure that I have good reputation so that } \\
\text { people will look up to me. }\end{array}$ & 2.25 & Untrue of me & \\
\hline $\begin{array}{l}\text { 4. I believe people need to show their achievements so } \\
\text { they could be respected. }\end{array}$ & 2.26 & Untrue of me & \\
\hline $\begin{array}{l}\text { 5. I believe that in business, deceit could not be } \\
\text { avoided. }\end{array}$ & 2.29 & Untrue of me & \\
\hline Average & 2.30 & Untrue of me & 3 \\
\hline \multicolumn{4}{|l|}{ Moving away from people (detached personality) } \\
\hline $\begin{array}{l}\text { 1. I know I could become successful even without the } \\
\text { help of other people. }\end{array}$ & 2.77 & True of me & \\
\hline $\begin{array}{l}\text { 2. I am confident that my business will be fine even if } \\
\text { people don't patronize it that much. }\end{array}$ & 2.78 & True of me & \\
\hline $\begin{array}{l}\text { 3. I believe conflict could be avoided if we avoid too } \\
\text { much interaction. }\end{array}$ & 2.68 & True of me & \\
\hline
\end{tabular}




\begin{tabular}{|l|c|c|c|}
\hline $\begin{array}{l}\text { 4. I make sure to live a very simple life so I won't need } \\
\text { to depend on others. }\end{array}$ & 2.79 & True of me & \\
\hline $\begin{array}{l}\text { 5. I believe it is important to know everything you need } \\
\text { to know so you can manage your own life. }\end{array}$ & 2.86 & True of me & \\
\hline Average & $\mathbf{2 . 7 8}$ & True of me & 1 \\
\hline Overall Average & $\mathbf{2 . 6 0}$ & & \\
\hline
\end{tabular}

Table 3 presents the respondents' central social coping trend. Having obtained the highest mean of 2.78 (true of me), the respondents claimed that they primarily possess the detached type of personality who tends to move away from people as their central social coping trend. Highest among the indicators is the item "I believe it is important to know everything you need to know so you can manage your own life" with a weighted mean of 2.86 verbally interpreted as true of me. The second central social coping trend employed by the respondents was to move towards people displaying the compliant type of personality with an average weighted mean of 2.72 (true of me). Highest among its indicators was "I am submissive to people who are in control of the situations" with 2.88 weighted mean verbally interpreted as true of me. The respondents do not utilize the moving-against-people social coping trend or aggressive personality since it obtained an average weighted mean of 2.30 interpreted as untrue of me.

With the central social coping trend Moving Away from People, the respondents manifested tendency to be independent and self-sufficient due to neurotic fear that intimate relationship could possibly lead to loss of identity and individuality (Nettman, 2013). The study of Polek et.al., (2011) examined migrant personality using the attachment framework. Upon comparing the personality of immigrants versus non-immigrants, they found out that immigrants are more secure and more dismissing compared to non-immigrants.

Table 4

Relationship between the Respondents' Cognitive Archetype and their Level of Acculturation

\begin{tabular}{|c|c|c|c|}
\hline Cognitive Archetype & Pearson r value & p-value & Interpretation \\
\hline Wise old man & $\begin{array}{c}-0.104 \\
\text { Low correlation }\end{array}$ & 0.963 & Not Significant \\
\hline Hero & $\begin{array}{c}-0.077 \\
\text { Negligible correlation }\end{array}$ & 0.422 & Not Significant \\
\hline Caregiver & $\begin{array}{c}-0.050 \\
\text { Negligible correlation }\end{array}$ & 0.603 & Not Significant \\
\hline Great father & $\begin{array}{c}-0.149 \\
\text { Low correlation }\end{array}$ & 0.121 & Not Significant \\
\hline Great mother & $\begin{array}{c}-0.088 \\
\text { Negligible correlation } \\
-0.082\end{array}$ & 0.360 & Not Significant \\
\hline Overall & Negligible correlation & 0.392 & \\
\hline Significance level @ 0.05 & & &
\end{tabular}

Table 4 shoes the relationship between the respondents' cognitive archetypes and their level of acculturation. All the respondents' cognitive archetypes Wise Old Man 
$(p=0.963)$, Hero $(p=0.422)$, Caregiver $(p=0.603)$, Great Father $(p=0.121)$, and Great Mother $(p=0.360)$ were not significantly related to their level of acculturation as shown in their computed $p$ values which are all higher than 0.05 level of significance. This indicates that the level of acculturation of the respondents is not dependent on whatever cognitive archetypes the respondents are manifesting.

Researches on the role of personality traits in acculturation show a number of contradictory findings (Kosic, 2006). The study of Bryant (2007) stated that the experience of immigration is not only due to one's personality but to the interaction of psychological, developmental and socio-cultural processes.

Table 5

Relationship between the Respondents' Cognitive Archetype and their Central Social Coping Trend

\begin{tabular}{|c|c|c|c|c|}
\hline \multirow{2}{*}{$\begin{array}{l}\text { Cognitive } \\
\text { Archetype }\end{array}$} & \multicolumn{4}{|c|}{ Central Social Coping Trend } \\
\hline & $\begin{array}{l}\text { Moving towards } \\
\text { people }\end{array}$ & $\begin{array}{l}\text { Moving Against } \\
\text { people }\end{array}$ & $\begin{array}{l}\text { Moving away } \\
\text { from people }\end{array}$ & Overall \\
\hline Wise old man & $\begin{array}{c}0.105 \\
\text { Low correlation } \\
p=0.276\end{array}$ & $\begin{array}{c}0.013 \\
\text { Negligible } \\
\text { correlation } \\
\mathrm{p}=0.893\end{array}$ & $\begin{array}{c}0.022 \\
\text { Negligible } \\
\text { correlation } \\
p=0.817\end{array}$ & $\begin{array}{c}0.063 \\
\text { Negligible } \\
\text { correlation } \\
p=0.572\end{array}$ \\
\hline Hero & $\begin{array}{c}0.140 \\
\text { Low correlation } \\
p=0.144\end{array}$ & $\begin{array}{c}0.008 \\
\text { Negligible } \\
\text { correlation } \\
p=0.937\end{array}$ & $\begin{array}{c}0.100 \\
\text { Low correlation } \\
p=0.297\end{array}$ & $\begin{array}{c}0.114 \\
\text { Low correlation } \\
p=0.236\end{array}$ \\
\hline Caregiver & $\begin{array}{c}0.134 \\
\text { Low correlation } \\
p=0.162\end{array}$ & $\begin{array}{c}0.031 \\
\text { Negligible } \\
\text { correlation } \\
p=0.751\end{array}$ & $\begin{array}{c}0.097 \\
\text { Negligible } \\
\text { correlation } \\
p=0.312\end{array}$ & $\begin{array}{c}0.119 \\
\text { Low correlation } \\
p=0.217\end{array}$ \\
\hline Great father & $\begin{array}{c}0.169 \\
\text { Low correlation } \\
p=0.077\end{array}$ & $\begin{array}{c}0.021 \\
\text { Negligible } \\
\text { correlation } \\
p=0.829\end{array}$ & $\begin{array}{c}0.114 \\
\text { Low correlation } \\
p=0.236\end{array}$ & $\begin{array}{c}0.139 \\
\text { Low correlation } \\
p=0.148\end{array}$ \\
\hline Great mother & $\begin{array}{c}0.111 \\
\text { Low correlation } \\
p=0.250\end{array}$ & $\begin{array}{c}0.041 \\
\text { Negligible } \\
\text { correlation } \\
p=0.671\end{array}$ & $\begin{array}{c}0.088 \\
\text { Negligible } \\
\text { correlation } \\
p=0.363\end{array}$ & $\begin{array}{c}0.102 \\
\text { Low correlation } \\
p=0.262\end{array}$ \\
\hline Overall & $\begin{array}{c}0.144 \\
\text { Low correlation } \\
p=0.132\end{array}$ & $\begin{array}{c}0.025 \\
\text { Negligible } \\
\text { correlation } \\
p=0.798\end{array}$ & $\begin{array}{c}0.094 \\
\text { Negligible } \\
\text { correlation } \\
p=0.327\end{array}$ & $\begin{array}{c}0.120 \\
\text { Low correlation } \\
p=0.213\end{array}$ \\
\hline
\end{tabular}

Table 5 shows the relationship between the respondents' cognitive archetypes and their central social coping trends. It clearly shows that all the computed $p$ values of the respondents' cognitive archetypes vis-à-vis their central social coping trend Moving Towards People ranged from 0.077 to 0.276 were all higher than 0.05 level of significance indicating 
no correlation. Same is true with the central social coping trend Moving Against People ( $p=$ 0.671 to 0.937 ) and Moving Away from People ( $p=0.148$ to 0.572 ) all higher than 0.05 level of significance. Such data clearly shows that the respondents' central social coping trend is not dependent to their cognitive archetypes. This result contradicts the result of the study conducted by Eksi (2010) who found out that personality traits are related to the subjects' coping trend.

Table 6

Relationship between the Respondents' Level of Acculturation and their Central Social Coping Trend

\begin{tabular}{|c|c|c|c|}
\hline Central Social Coping Trend & Pearson $\mathbf{r}$ value & p-value & Interpretation \\
\hline Moving towards people & $\begin{array}{c}-0.148 \\
\text { Low correlation }\end{array}$ & 0.123 & Not Significant \\
\hline Moving against people & $\begin{array}{c}0.038 \\
\text { Negligible correlation }\end{array}$ & 0.695 & Not Significant \\
\hline Moving away from people & $\begin{array}{c}-0.212 \\
\text { Low correlation }\end{array}$ & $0.026^{*}$ & Significant \\
\hline Overall & $\begin{array}{c}-0.152 \\
\text { Low correlation }\end{array}$ & 0.113 & Not Significant \\
\hline
\end{tabular}

*Significant @ 0.05

Table 6 shows the relationship between the respondents' level of acculturation and their central social coping trends. Both the central social coping trends Moving Towards People and Moving Against People obtained $p$ values of 0.123 and 0.695 respectively indicating no significant relationship. On the other hand, the respondents' level of acculturation is inversely correlated to their central social coping trend Moving Away from People as shown in the computed $p$ value of 0.026 which is lower than 0.05 level of significance. This means the lower the respondents' level of acculturation, the more they tend to move away from people displaying the detached type of personality. Schmitz (1994) as cited by Jasinskaja-Lahti et. al (2003) emphasized that acculturation is related to variety of personality characteristics which eventually might be related to coping styles and health behaviors.

\section{Conclusions and Recommendations}

After analyzing the significant findings, the following conclusions were draws: the respondents' dominant cognitive archetype is Great Mother meaning they have the tendency to manifest essential traits of mothers such as their cherishing and nourishing goodness who shows genuine empathy (Schwartz, et. al., 2010); they have low level of acculturation meaning they did not necessarily embrace the changes even they are in contact with culturally different people of social influences (Michalski \& Shackelford, 2010); they utilized the central social coping trend Moving Away from People or Detached personality which implies that the respondents manifested tendency to be independent and self-sufficient due to neurotic fear that intimate relationship could possibly lead to loss of identity and individuality (Nettman, 2013). It was also shown that the level of acculturation of the respondents was not dependent on their cognitive archetypes and that their central social coping trend is also not dependent to their cognitive archetypes. On the other hand, a significant relationship was noted between the respondents' level of acculturation and their central social coping trend Moving Away 
from People which indicated that the lower the respondents' level of acculturation, the more they tend to move away from people displaying the detached type of personality.

Economic, political, and social challenges are forcing people to seek refuge in places and circumstances where they feel opportunities might work to their advantage. But immigration challenges might take its toll on individuals who are not prepared and not resilient enough to cope with such struggles. An understanding of immigrants' uniqueness and complexities is needed to empower these people. This study supports that idea of the evolutionary theory that Muslim immigrants possess an adaptive process which is an evolved strategy that solve important survival and/or reproductive problems. Having insights about relevant coping mechanism and strategies is also beneficial for this will serve as a motivation for other who also facing the same challenges. Hence, this study could be an addition to the many resources that aims to uplift the morale of immigrants worldwide.

It is important that Muslim immigrants continuously look after and care for each other especially in an environment quite different from where they use to reside. It is also important for them to contribute in their own way by showing their attachment and loyalty to their new home. The locals of Binan on the other hand need to be more accepting by recognizing and appreciating diversity and show an inclusive understanding of Muslim identity. Local social service personnel or even municipal personnel are also expected to extend assistance to the Muslim community by establishing and implementing stress-copingacculturation-adaptation framework that will meet the needs of these migrants. Lastly, a further study on the attitudes and behaviors of locals towards the Muslim migrants should also be conducted, for through its results will pave the way for a more positive relationship.

\section{References}

Adamski S. (2011) Archetypes, collective unconscious and quantum psychology. NeuroQuantology. September 2011 | Vol 9 | Issue 3 | Page 563-571.

Bazezew, A., \& Neka, M. (2017). Interpersonal conflicts and styles of managing conflicts among students at Bahir Dar University, Ethiopia. Journal of Student Affairs in Africa | Volume 5(1) 2017, 27-39 | 2307-6267 | DOI: 10.14426/jsaa.v5i1.2480 27.www.jsaa

Bodycott, P. (2015). Intragroup conflict during study abroad. ISSN: 2162-3104 Print/ ISSN: 2166-3750 Online Volume 5, Issue 3 (2015), pp. 244-259 @ Journal of International Students http://jistudents.org/

Bryant, J. (2007). Understanding immigration and psychological development: a multi-level ecological approach. Online Submission, Journal of Immigrant \& Refugee Studies. v5 n4 p27-48 2007. http://jirst.haworthpress.com

Bueza, M. (2015). MAP: Islam in the Philippines. Rappler IQ. Published 5:22 PM, July 17, 2015 Updated 5:22 PM, July 17, 2015. Retrieved:

https://www.rappler.com/newsbreak/iq/99572-map-islam-philippines

Burger, J. (2012) Personality an introduction Philippine edition. Cengage Learning Asia Pte.Ltd.: Manila, Philippines

Buss, D. (2009) How can evolutionary psychology successfully explain personality and individual differences? Sage Journals. Vol 4, Issue 4, February 1, 2009. Retrieved: https://doi.org/10.1111\%2Fj.1745-6924.2009.01138.x

Buss, D., \& Hawley, P. (2011). The evolution of personality and individual differences. Oxford University Press. Retrieved: 
https://books.google.com.ph/books?hl=en\&|r=\&id=DcLJBLbFNowC\&oi=fnd\&pg=PR5 $\& d q=d a v i d+$ buss+evolutionary+theory+of+personality\&ots=WWoCynln8C\&sig=oF_h eAI_DOK4BTBvTq4P-K-

6Jfo\&redir_esc=y\#v=onepage\&q=david\%20buss\%20evolutionary\%20theory\%20of\%2 Opersonality $\& \mathrm{f}=\mathrm{false}$

Eberhart, N., \& Hammen, C. (2010). Interpersonal style, stress, and depression: an examination of transactional and diathesis-stress models. Journal of Social and Clinical Psychology January 2010, Vol. 29, No. 1: pp. 23-38. Retrieved: https://doi.org/10.1521/jscp.2010.29.1.23

Eksi, H. (2010). Personality and coping among Turkish college students: a canonical correlation analysis. Educational Sciences: Theory \& Practice

Fassaert, T., De Wit, M., Tuinebreijer, W., Knipscheer, J., Verhoeff, A., Beekman, A., \& Dekker, J. (2011). Acculturation and psychological distress among non-Western Muslim migrants - a population-based survey. International Journal of Social Psychiatry. Vol 57, Issue 2, 2011. Retrieved: https://doi.org/10.1177\%2F0020764009103647

Frazer, A., Rubens, S., Johnson-Montoyama, M., DiPierro, M., Fite, P. (2017). Acculturation dissonance, acculturation strategy and delinquency in Latina/o adolescence. Child \& Youth Care Forum, v46 n1 p19-33 Feb 2017. ERIC number EJ1126361, ISSN-1053-1890

Golden, C. (2013). The 12 common archetypes. Retrieved http://www.gxunanning.com/scic_2013_2014/documents/The_12_Common_Archet ypes.doc

Harlow, H. (2016) Horneys coping strategies. European Medical Alliance. Retrieved: https://www.europeanmedical.info/cognitive-therapy/horneys-copingstrategies.html

Harris, C. (2016) A description of Karen Horney's neo-Freudian theory of personality. Retrieved: https://owlcation.com/social-sciences/A-Description-of-Karen-HorneysNeo-Freudian-Theory-of-Personality-and-Psychopathology

Inglehart, R., \& Norris, P. (2009) Muslim integration into western cultures: between origins and destinations. Digital Access to Scholarship at Harvard. Harvard Library Office for Scholarly Communication. Retrieved:

http://web.hks.harvard.edu/publications/workingpapers/citation.aspx?Publd=6478

Jamalinesari, A \& Feilinezhad, N. (2015). Mental self-exploration in Samuel Beckett's Molloy: a Jungian approach. Advances in Language and Literary Studies ISSN: 2203-4714 Vol. 6 No. 1; February 2015

Jasinskaja-Lahti, I., Liebkind, K., Horenczyk, G., \& Schmitz, P. (2003). The interactive nature of acculturation: perceived discrimination, acculturation attitudes and stress among young ethnic repatriates in Finland, Israel and Germany. International Journal of Intercultural Relations 27 (1), 79-97, 2003

Juaseekoon, S., Pholprasert, A., \& Rukspollmuang, C. (2017). The effects of the living together through art (LTAA) model on promoting the consciousness of living together between Thai and migrant students. International Electronic Journal of Elementary Education. December 2017, Volume 10, Issue 2. ISSN:1307-9298.,www.iejee.com

Khader, B. (2016). Muslims in Europe: the construction of a "problem". Open Mind. Europe: Contrasting Approach. Retrieved: https://www.bbvaopenmind.com/en/articles/muslims-in-europe-the-constructionof-a-problem/ 
Kosic, A. (2006) Personality and individual factors in acculturation. American Psychological Association. Cambridge University Press, 2006. psycnet.apa.org

Lee, J., \& Negrelli, K. (2018) Cultural identification, acculturation, and academic experience abroad: a case of a joint faculty-led short-term study abroad program. ISSN: 21623104 Print/ ISSN: 2166-3750 Online Volume 8, Issue 2 (2018), pp. 1152-1072 @ Journal of International Students http://jistudents.org/doi: 10.5281/zenodo.1250417

Liebert, S., Siddiqui, M., \& Goerzig, C. (2020). Integration of Muslim immigrants in Europe and North America: a transatlantic comparison. Journal of Muslim Minority Affairs. Vol. 40 Issue 2, p196-216. 21p. 3 Charts. DOI: 10.1080/13602004.2020.1777663.

Masanda, A. (2018). RPm comprehensive reviewer Volume 1: Lecture Notes. Jenher Publishing House. Rodriguez, Rizal. ISBN:978-621-8038-14-1

McCallister, J. (2018) Acculturation: definition, theory \& examples. Study.com. Retrieved: https://study.com/academy/lesson/acculturation-definition-theory-examples.html

Michalski, R., \& Shackelford, T. (2010) Evolutionary personality psychology: reconciling human nature and individual differences. Elsevier. Personality and Individual Differences. Volume 48, Issue 5, April 2010, Pages 509-516. Retrieved: https://doi.org/10.1016/j.paid.2009.10.027

Munteanua, A., Costeaa, I., Palosa, R., \& Jinaru, A. (2010) Entering in the essences of personality - studies over archetypes. Procedia Social and Behavioral Sciences 5 (2010) 2272-2276. Retrieved:

https://www.sciencedirect.com/science/article/pii/S1877042810018227

Narang, K., Chung, A., Sundaram, H., Chaturvedix, S., (2019). Discovering archetypes to interpret evolution of individual behavior. arXiv:1902.05567v2 [cs.SI]

Nettman, R. (2013). Moving towards, against and away from people: the relationship between karen horney's interpersonal trends and the enneagram. Retrieved: https://core.ac.uk/download/pdf/43173777.pdf

Polek, E., Van Oudenhoven, J., \& TenBerge, J. (2011). Evidence for a "migrant personality": attachment styles of Poles in Poland and Polish immigrants in Netherlands. Journal of Immigrant \& Refugee Studies 9 (4), 311-326, 2011

Purrington, M. (2019). The mother archetype. Carl Jung depth psychology. Life, Works and Legacy of Carl Jung. Retrieved:

https://carljungdepthpsychologysite.blog/2019/03/13/the-motherarchetype/\#.XQcri4gzblU

Salma, J., \& Salami, B. (2020). Growing old is not for the weak of heart: social isolation and loneliness in Muslim immigrant older adults in Canada. Health \& Social Care in the Community. Mar2020, Vol. 28 Issue 2, p615-623. 9p. DOI: 10.1111/hsc.12894.

Schmitz, P. (1994). Acculturation and adaptation process among immigrants in Germany: journeys into cross-cultural psychology. Subtitle: Selected papers from the Eleventh International Conference of the International Association. researchgate.net

Schwartz, S., Unger, J., Zamboanga, B., \& Szapocznik, J. (2010). Rethinking the concept of acculturation. Implications for Theory and Research. HHS Public Access. AmPsycol. 2010 May-June; 65(4) 237-251 doi: 10.10371/a0019330. Retrieved: https://www.ncbi.nlm.nih.gov/pmc/articles/PMC3700543/

Sharma, A., Joyner, A., \& Osment, A. (2014). Adverse impact of racial Isolation on student performance: a study in North Carolina. Education Policy Analysis Archives A peerreviewed, independent, open access, multilingual journal. Volume 22 Number 14 March 10th, 2014 ISSN 1068-2341 
Sullivan, C., \& Kashubeck-West, S. (2015) The interplay of international students' acculturative stress, social support, and acculturation modes. ISSN: 2162-3104 Print/ ISSN: 2166-3750 Online Volume 5, Issue 1 (2015), pp. 1-11, @Journal of International Students. http://jistudents.org/

Swann, W. B. Jr., \& Bosson. J. (2008). Identity negotiation: a theory of self and social interaction. In O. John., R. Robins \& L. Pervin (Eds.), Handbook of personality psychology: Theory and research (pp. 448-471). New York: Guilford.

Telzer, E. (2011). Expanding the acculturation gap distress model: an integrative review of research. Human Development 2010; Karger Medical and Scientific Publishers 53:313-340 DOI:10.1159/000322476

Tessier, D., Sarrazin, P., \& Sarrazin, N. (2010). The effect of an intervention to improve newly qualified teachers' interpersonal style, students' motivation and psychological need satisfaction in sport-based physical education. Contemporary Educational Psychology. Volume 35, Issue 4, October 2010, Pages 242-253. Retrieved: https://www.sciencedirect.com/science/article/pii/S0361476X10000305

Villate, V. (2012). The qualitative report 2012 Volume 17, Article 76, 1-9. Retrieved: http/www.nova.edu/SSS/QR/QR17/villate.pdf

Zaker, A. (2016) The acculturation model of second language acquisition: inspecting weaknesses and strengths. Indonesian EFL Journal, Vol. 2(2) July 2016 p-ISSN 22527427 e-ISSN 2541-3635. Retrieved:

https://www.researchgate.net/publication/315060938_The_Acculturation_Model_o f_Second_Language_Acquisition_Inspecting_Weaknesses_and_Strengths

Ziegenbein, M., Calliess, I., Sieberer, M., \& Machleidt, W. (2008). Current psychiatry reviews, Volume 4, Number 1, 2008, pp. 39-47(9). Bentham Science Publishers. https://doi.org/10.2174/157340008783743776 